\title{
Methodological parameters to induction of second- degree thermal injuries in experimental model
}

\section{Sabrina de Oliveira Capella ${ }^{1, *}$, Mariana Teixeira Tillmann ${ }^{2}$, Cristina Gevehr Fernandes ${ }^{1}$, Márcio Fernando Weber Brito ${ }^{1}$, Gabriela Morais Santana ${ }^{1}$, Anelize de Oliveira Campelo Félix ${ }^{1}$ and Márcia de Oliveira Nobre ${ }^{1}$}

\begin{abstract}
${ }^{1}$ Universidade Federal de Pelotas. Faculdade de Veterinária. Caixa Postal 354. Campus Universitário. Pelotas-RS, Brazil (CEP 96010-900) *Email: capellas.oliveira@gmail.com. ${ }^{2}$ Universidade do Oeste de Santa Catarina. Faculdade de Medicina Veterinária. Unoesc Xanxerê. Rodovia Rodovilho Bortoluzzi. Barro Preto. Xanxerê-SC, Brasil (CEP 89820-000).
\end{abstract}

\begin{abstract}
Thermal injuries present a high severity potential, affecting adjacent organs with functional loss and even methabolic, cardiovascular and pulmonary disorders that can lead the animal to death. Over time, companion animals started to share smaller spaces and living very close to humans, due to these changes cases of thermal burns have been increasing. Therefore, studies embracing this area are needed, considering the skin tissue and its attachments loss have repercussions in thequality of the wound healing. The complexity of this kind of skin injuries does not allow in vitro experiments to clarify its pathophysiology, being necessary to use experimental animals to replicate a thermal injury corectly, in the same way that we have a diversity of methodologies for inducing termal burns, and yet there is no such padronization for the development of a type of injury. In this scenario, the purpose of the study is to stablish methodological parameters for the induction of second-degree thermal lesions. Six Wistar rats were used, creating, with the help of cubic-tipped metallic device, two lesions on the back of each animal, one in the thoracic region and the other in the abdominal region. Different temperatures $\left(90^{\circ} \mathrm{C}\right.$ and $\left.100{ }^{\circ} \mathrm{C}\right)$ were applied in different times of contact with the skin $(10 \mathrm{~s}$, $15 \mathrm{~s}$ and $20 \mathrm{~s}$ ), each animal received a temperature and time of exposure for both lesion sites. After three days the animals were euthanized, a photographic record was created and the injured skin sites were collected to evaluate the extent of the lesion by digital planimetry. Skin samples were processed and stained with hematoxicillin-eosin. It was observed that lesions in the abdominal region with higher temperature $\left(100^{\circ} \mathrm{C}\right)$ and longer exposure time (15 s and $20 \mathrm{~s}$ ) showed an expansion in the diameter of the initial thermal lesion, whereas lesions of the thoracic region with lower temperature $\left(90^{\circ} \mathrm{C}\right)$ and time of exposure $(10 \mathrm{~s})$ showed a reduction related to the initial lesion size. Regarding the histopathological parameters, it was determined that wounds performed in the thoracic region and that remained longer in contact to high temperatures $\left(90^{\circ} \mathrm{C}\right.$ and
\end{abstract}

Received

November 30, 2018

Accepted

December 28, 2018

Released

December 31, 2018

Full Text Article

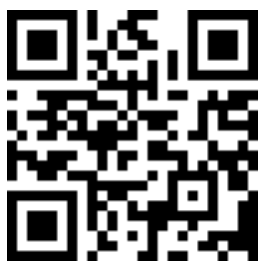

ORCID

(D) 0000-0001-8252-2096 Sabrina de Oliveira Capella

(D) 0000-0002-8693-2567

Mariana Teixeira Tillmann

D 0000-0002-0729-2099 Cristina Gevehr Fernandes

(D) 0000-0001-9099-4050

Márcio Fernando Weber Brito 
$100{ }^{\circ} \mathrm{C}$ ) presented greater severity, whereas lesions located in the abdomen and with a shorter time of exposure to high temperatures were lower. Thus, it is concluded that to obtain standardized second-degree wounds it must be applied temperatures between $90{ }^{\circ} \mathrm{C}$ and $100{ }^{\circ} \mathrm{C}$, for $15 \mathrm{~s}$ or $20 \mathrm{~s}$, in the thoracic region.

Keywords: Thermal injuries; Rats; Necrosis; Temperature; Lesion site.

\section{Introduction}

The high frequency of cutaneous lesions cases in the veterinary clinical practice, due different causes, requires attention to know the wound in each situation (Tillmann et al., 2015). Cases of burn injuries in animals can lead to severe metabolic changes, cardiovascular and pulmonary disorders, and even more important is knowledge about this kind of injury (Vaughn and Beckel, 2012).

The skin is an important organ responsible for the protection against external agents and thermoregulation of the body, it is composed by two layers, the epidermis and the dermis. The first is a stratified keratinized epithelium organized in sublayers, which regenerate by cell division (Bragulla, 2004). The dermis is a thick conjunctival basal layer, with innumerous cell types. Fibroblasts, fibrocytes, collagen and elastic fibers allow elasticity and resistance of the skin, in addition to blood capillaries that nourish the epidermis without penetrating it, sensory nerve endings and skin attachments (Blanes, 2004).

In an accidental burn occurs the imbalance of skin hydroelectrolytic homeostasis, impairing temperature control and flexibility of body surface. The implication of injured skin depends on the extent and depth of the lesions, being classified in first, second or third degree (Rocha, 2009). First-degree lesions are considered superficial, affecting only the epidermis and their cells may present with cytoplasmatic vesiculation, in addition to mild hyperemia of the tissue's blood vessels.
Second-degree lesions may be divided into two subtypes, superficial second degree and deep second degree. The first one is considered partial thickness, reaching the epidermis completely and the dermis partially; the second one progresses throughout the epidermis and dermis without damaging adjacent structures. Second-degree wounds may include germinative epithelium destruction, erythrocyte agglutination, and severe hyperemia in adjacent tissues. While third degree lesions, with total thickness, present coagulative necrosis of the epidermis, total dermis and even structures attached to the subcutaneous. In this type of lesion, it is observed an intense leakage of deep blood vessels, peripheral vessel hyperemia and subcutaneous edema (Wohlsein et al., 2016).

In small animals burns are usually caused by hot liquids, animal dryers, heated mattresses and electric wire bites (Vaughn and Beckel, 2012). Superficially, the injuries are extensive, erythematous and quite painful, capable of presenting edema, inflammation and scarification in severe cases that may require surgical therapy to effective treatment (Albernaz et al., 2015). An understanding of the clinical signs combined to the knowledge of the physiopathology in cases of thermal burns is indispensable to the development of studies about different treatments for this kind of injury. In the veterinary medicine field, there are only a few studies that address the subject, so references of human medicine are often used in order to gain information to 
apply it in veterinary patients (Vaughn and Beckel, 2012). In vivo experimental studies help to understand the pathophysiological process of the thermal burn, since this is a complex pathophysiology that impedes the establishment of an ideal experimental animal model (Abullahi et al., 2014). In addition, there is a difficulty to determinate the severity of an injury, especially when it occurs due different causes (by contact, electrical or scalds), and is once reflected to experimental models (Andrews and Cuttle, 2017). Therefore, although we have a heterogenicity of materials used to make thermal burns and an appliance of new models that aim to replicate a desired type of thermal injury, the best way for doing it is not yet stablished. Thus, the objective of this study is to derminate methodological parameters in relation to time, temperature and site, to a standardized second-degree thermal burns.

\section{Methodology}

Two thermal burns were induced in the dorso of Wistar rats, the first one in the thoracic region, the second in the abdominal region $(n=12)$, males, adults. The animals were anesthetized using isoflurane in a continuous flow, and the trichotomy (electric trichotomous with a 10 blade razor) and antisepsis (alcohol $70 \%$ ) of the animals' back were first performed. The thermal burns were induced using a metal device with a cubic tip $\left(4 \mathrm{~cm}^{2}\right)$ (Campelo, 2011; Kim et al., 2016) that was placed in contact with the animal's skin at different temperatures $\left(90{ }^{\circ} \mathrm{C}\right.$ and $\left.100{ }^{\circ} \mathrm{C}\right)$ and time of contact with the skin $(10 \mathrm{~s}, 15 \mathrm{~s}$ and $20 \mathrm{~s}$ ) (Table 1). During intraoperation e and postoperation periods, the animals received analgesia with subcutaneous application of tramadol hydrochloride $(10 \mathrm{mg} / \mathrm{kg})$ one time a day. The study was approved by the Ethics and Animal Experimentation Commission, of the Federal University of Pelotas under No. 1878/2016.

After three days, the lesions were clinically evaluated for lenght and the animals were euthanized by anesthetic overdose according to Normative CONCEA's Resolution no. 37, of January, 2018 (Brasil, 2018). To evaluate the extension of the wound, the photographic record of each lesion was made using a digital camera (Samsung ES17) fixed to the tripod at $15 \mathrm{~cm}$ from the wound. The image obtained was treated with the program GIMP $2 \AA$ and Image $\mathrm{J} 囚$, determining the area of the lesion in $\mathrm{cm}^{2}$ and calculating the reduction or expansion percentage, taking as an initial measure the size of the device used to create the lesions $\left(4 \mathrm{~cm}^{2}\right)$ considered the $100 \%$ size. The next step was collecting skin samples from the induced thermal wounds. They were fixed in $10 \%$ formalin, processed and stained with hematoxylin and eosin. In the histopathological study, the presence/absence of erythrocytes, hyperemia and reepithelialization were evaluated. Besides the extent of necrosis classified as epithelial, epithelial and superficial dermis or epithelial dermis and deep dermis, and also the extent of the attachments necrosis (superficial or deep) and the amount of inflammatory infiltrate (mild, moderate or exuberant). The data was tabulated and evaluated in the study of the lesionated area, statistically, using $\mathrm{T}$ studant test in the Microsoft excel software and the hitopathological data were evaluated in percentage, obtained from a simple rule of three. 
Table 1. Injuries' identification according temperature applied, contact time of the device on the animal's skin and body region that was applied.

\begin{tabular}{cccc}
\hline Injury & $\begin{array}{c}\text { Temperature } \\
\left({ }^{\mathbf{C}} \mathbf{C}\right.\end{array}$ & $\begin{array}{c}\text { Contact time } \\
(\mathbf{s})\end{array}$ & Body Region \\
\hline 1 & 90 & 10 & Thorax \\
\hline 2 & 100 & 10 & Thorax \\
\hline 3 & 90 & 15 & Thorax \\
\hline 4 & 100 & 15 & Thorax \\
\hline 5 & 90 & 20 & Thorax \\
\hline 6 & 100 & 20 & Abdomen \\
\hline 7 & 90 & 10 & Abdomen \\
\hline 8 & 100 & 10 & Abdomen \\
\hline 9 & 90 & 15 & Abdomen \\
\hline 10 & 100 & 15 & Abdomen \\
\hline 11 & 90 & 20 & Abdomen \\
\hline 12 & 100 & 20 &
\end{tabular}

\section{Results}

\section{Extension of the injuries}

It was observed that the highest temperature applied $\left(100{ }^{\circ} \mathrm{C}\right)$ expanded on average $17 \%$ of njury area in relation to the original size of the metal model, while the wounds that received lower temperature $\left(90{ }^{\circ} \mathrm{C}\right)$ reduced on average $13 \%$ (Table 2). When the contact time of the device on the skin surface was observed, the shortest exposure time (10 s) had a lesion size reduced by $9 \%$ while the remaining times (15 s and $20 \mathrm{~s}$ ) showed an increase of $8 \%$ and $5 \%$ on average respectively (Table 3 ). On the other hand, differences were seen between the two lesions sites, in the thoracic region it showed a reduction of $4 \%$ regarding the initial size and the abdominal region an increased average of $8 \%$ (Table 4 ).

Table 2. Average injuries area and expansion or reduction percentage regarding the temperature applied, three days after the wound was induced.

\begin{tabular}{cccc}
\hline Temperature $\left({ }^{\circ} \mathbf{C}\right)$ & Average $\left(\mathbf{c m}^{2}\right)$ & Expansion (\%) & Reduction (\%) \\
\hline 90 & $3,47^{a}$ & - & 13 \\
\hline 100 & $4,67^{a}$ & 17 & - \\
\hline
\end{tabular}

Different letters represent different statiscally frequencies $(\mathrm{P}<0,05)$.

Table 3. Average injuries area and expansion or reduction percentage regarding contact time in the skin, three days after the wound was induced.

\begin{tabular}{cccc}
\hline Time (s) & Average $\left.\mathbf{( c m}^{\mathbf{2}}\right)$ & Expansion (\%) & Reduction (\%) \\
\hline 10 & $3,66^{\mathrm{a}}$ & - & 9 \\
\hline 15 & $4,35^{\mathrm{a}}$ & 8 & - \\
\hline 20 & $4,21^{\mathrm{a}}$ & 5 & - \\
\hline
\end{tabular}

Different letters represent different statiscally frequencies $(\mathrm{P}<0,05)$. 
Table 4. Average injurie's area and expansion or reduction percentage regarding application time, three days after the wound was induced.

\begin{tabular}{cccc}
\hline Site & Average $\left(\mathbf{c m}^{\mathbf{2}}\right)$ & Expansion (\%) & Reduction (\%) \\
\hline Thorax & $3,82^{\mathrm{a}}$ & - & 4 \\
\hline Abdomen & $4,32^{\mathrm{a}}$ & 8 & - \\
\hline
\end{tabular}

Different letters represent different statiscally frequencies $(\mathrm{P}<0,05)$.

\section{Histopathological study}

The thermal wounds induced on the thorax presented on the necrosis extension parameter $67 \%$ of epidermal and deep dermis involvement, $16.7 \%$ of epidermis and superficial dermis, and $16.7 \%$ of epidermis only. While in the abdominal region $17 \%$ presented degeneration in the epidermis and deep dermis, $50 \%$ in the epidermis and superficial dermis and $33 \%$ only in the epidermis. It was observed that $67 \%$ of the thoracic lesions reached deeply the attachments of the skin and 33\% the superficial form, while on the abdominal lesions $50 \%$ reached deeply the attachments and $50 \%$ superficially. The inflammatory infiltrate was more intense in the thorax lesions, it was observed in $83 \%$ of the lesions as moderate and in $17 \%$ as mild, whereas in the abdominal lesions inflammatory infiltrate was mild in all the lesions (100\%). Presence/ absence of free erythrocytes, hyperemia and reepithelialization, were similar to the lesions of the thorax and abdomen, presenting in both $50 \%$ of free erythrocytes, $100 \%$ prevalence of hyperemia and $100 \%$ absence of reepithelialization.

The exposure time of the skin under different temperatures $\left(90^{\circ} \mathrm{C}\right.$ and $100{ }^{\circ} \mathrm{C}$ ) was a determinant factor in the lesion severity. Thermal injuries that were induced by $10 \mathrm{~s}$ of thermal contact, presented $75 \%$ of epidermal necrosis and $25 \%$ of epidermal and superficial derme necrosis; $75 \%$ of skin attachments necrosis and $25 \%$ of deep necrosis. Tissue necrosis in the epidermis and deep dermis (50\%), and epidermis and superficial dermis $(50 \%)$ occurred at the others time sets (15 "and 20"). Observing the skin attachments necrosis parameter, the application times of $15^{\prime \prime}$ and 20" presented $75 \%$ of superficial attachments necrosis and in 25\% the necrosis were deep. Free erythrocytes were seen in only $25 \%$ of the $10 \mathrm{~s}$ lesions, whereas in those wounds which were resulted by an exposure of $15 \mathrm{~s}$ and $20 \mathrm{~s}$ the erythrocytes were found in 75 and $100 \%$, respectively. The wounds resulted by a thermal exposure of $10 \mathrm{~s}$ presented $75 \%$ of slight inflammatory infiltrate and in $25 \%$ moderate, while in the $15 \mathrm{~s}$ and $20 \mathrm{~s}$ exposures the level of slight inflammatory infiltrate was lower $(50 \%)$ and moderate infiltrate was higher (50\%). Hyperemia was present in all wounds regardless of the exposure time, whereas reepithelialization was not observed in any other sample in the time of the study.

Regarding different temperatures applied $\left(90^{\circ} \mathrm{C}\right.$ and $\left.100^{\circ} \mathrm{C}\right)$, no association between a higher temperature and increase of lesion severity was observed. Wounds made under $90{ }^{\circ} \mathrm{C}$ showed extension of tissue necrosis $33 \%$ only on epidermis, $17 \%$ of epidermis and superficial dermis and $50 \%$ of epidermis and deep dermis. As for necrosis of skin attachments, there was $33 \%$ of superficial necrosis and $67 \%$ deep necrosis. The inflammatory infiltrate was seen in $67 \%$ of the samples as mild and $33 \%$ as moderate, while reepithelialization was absent in $100 \%$ of the lesions. The free erythrocytes were present in $50 \%$ of the wounds and again the hyperemia was present in all $(100 \%)$ of the wounds, regardless the temperature applied. 
Using a $100{ }^{\circ} \mathrm{C}$ temperature it occured tissue necrosis only in $17 \%$ of the epidermis, $50 \%$ of the epidermis and superficial dermis and $33 \%$ of the epidermis and deep dermis. It was also observed that $50 \%$ of the skin attachments presented superficial necrosis and 50\% deep necrosis. As for the inflammatory infiltrate, the same behavior happened, with $50 \%$ being classified as mild and $50 \%$ as moderate, free erythrocytes were present in $83 \%$ of the lesions, and in all samples were observed hyperemia (100\%) and absence of re-epithelialization (100\%).

\section{Discussion}

Clinically the thermal injuries using $90^{\circ} \mathrm{C}$ or $10 \mathrm{~s}$ or that ones made in thoracic region showed reduction in the initial diameter of the lesions demonstrating greater control in the size induced by the cubic-tipped metallic device used. Rats are classified as "loose skin" animals because they have a great skin elasticity and lack of adherence to adjacent structures (Abdullahi et al., 2014), which probably favored the contraction of the skin in response to the thermal stimulation on a more evident way in the abdominal region, because this region does not have the bone structure present in the thoracic region. Thus, it can be observed that although the analyzed parameters do not present significant differences in the size of the lesion caused, it is attentive the fact that lower temperature and time of exposure in the thoracic region, produces a better standardized lesion.

In the histopathological analysis the exposure time and the body region influenced on the the severity of the lesions and consequently the degree of burnthat was caused. Lesions made in the thoracic region and that spent more time in contact with heated metal of the device at both temperatures $\left(90{ }^{\circ} \mathrm{C}\right.$ and $100{ }^{\circ} \mathrm{C}$ ) showed greater severity in the analyzed parameters. Thus, allowing classification in 2nd to 3rd degree burns, depending on the exposure time. Regarding the lesions induced in the abdominal region, with a shorter exposure time at the temperatures proposed in this study, thermal lesions can be classificated from $1{ }^{\circ} \mathrm{C}$ to $2{ }^{\circ} \mathrm{C}$ superficial degree. While the different temperatures $\left(90^{\circ} \mathrm{C}\right.$ and $\left.100^{\circ} \mathrm{C}\right)$ did not seem to influence on the severity of the lesion. Possibly because of the small break between temperatures, and also because extreme temperatures were not applied, since it was demonstrated variations in the extent of thermal injuries when temperatures varying between $100{ }^{\circ} \mathrm{C}$ and $200{ }^{\circ} \mathrm{C}$ reaching different degrees of tissue destruction (Campello et al., 2011).

In the shorter exposure time $(10$ s) the temperature caused less damage to the blood capillaries, and less damage to the tissue which reflected in a milder inflammatory response. The inflammatory infiltrate is one of several actions that occurs on the first phase of the wound healing process, a few minutes after the trauma occurs it starts a vasodilation that increases blood flow and vascular permeability at the wound site, allowing the migration of neutrophils and macrophages into the tissue, for the debridement of the wound (Medeiros and Dantas Filho, 2016). The most intense inflammatory infiltrate in the thoracic lesions is probably related to an area of deeper necrosis, which stimulated the local immune response to tissue recovery. In this region the ribs can provide greater pressure with the device compressing the cutaneous tissue, which allows faster heat propagation to deeper tissues that in that way, are approximated near the heat source. In addition, tissue compression can reduce blood supply, delaying heat dissipation that contributes to deeper burn (Singer et al., 2011).

In this study the severity of tissue injuries was progressively increased with the exposure time of the skin under high temperature. Condition also seen in a study with suine experimental model, in 
which longer the tissue exposure time to higher temperatures, greater were the deeper damages severity (Singer et al., 2011). Probably due to the fact that longer contact time allows the heat propagation through adjacents tissues increasing the damages severity (Santos e Santos, 2017).

Therefore, to improve the methodology for inducing thermal injuries in murine models, it is determinated that injuries induced in the thoracic area provide a size closer to the real size induced by the thermal conduction device. However, in that area the injuries tend to have greater severity with a bigger extent of tissues and skin attchments necrosis and stronger inflammatory reaction, thus allowing to replicate second and third degree injuries. In addition, small temperature differences did not interfere with the intensity of the injury, but the contact time with the skin has shown to be directly related to the injury extent, the longer the time, the greater the injury depth and greater the skin attachments destruction, greater the severity of inflammatory response, consequently higher the burn degree.

This study evidenced a replication of standardized thermal injuries allowing the research of methods and products to optimize the adequate tissue repair of burn patients, showing the tissue repercussion in different temperatures, exposure time in body regions that are important to be recognized for different approaches to each type of injury, qualifying the treatment of thermal injuries in the veterinary practice.

\section{Conclusion}

The $15 \mathrm{~s}$ and $20 \mathrm{~s}$ exposure time of the skin in the thoracic region, under the heat of $90{ }^{\circ} \mathrm{C}$ and $100{ }^{\circ} \mathrm{C}$ provide a second degree thermal injury. While the time of $10 \mathrm{~s}$ of skin contact at temperatures of $90{ }^{\circ} \mathrm{C}$ and $100{ }^{\circ} \mathrm{C}$ in the abdominal region, were not enough to replicate a second degree injury.

\section{Acknowledgments}

CAPES and CNPq (310619/2016-

5 ) for the granting of scholarships and financial support.

\section{Conflict of interest}

Authors declare that they have no conflict of interests.

\section{References}

Abdullahi, A.; Amini-Nik, S.; Jeschke, M. G. Animal models in burn research. Cellular and Molecular Life Sciences, v. 71, no. 17, p 3241-3255, 2014. https://doi.org/ 10.1007/s00018-014-1612-5

Albernaz, V. G. P.; Ferreira, A. A.; Castro, J. L. C. Queimaduras térmicas em cães e gatos. Veterinária e Zootecnia, v. 22, p. 322-334, 2015.

Andrews, C. J.; Cuttle, L. Comparing the reported burn conditions for different severity burns in porcine models: A systematic review. International Wound Journal, $\quad$ v. 14, p.1199-1212, 2017. https://doi.org/10.1111/iwj.12786

Blanes, L. Tratamento de feridas. In: BaptistaSilva, J.C.C. Cirurgia vascular: guia ilustrado. 1. ed. São Paulo: Baptista-Silva JCC, 2004.

Bragulla, H.; Budras, D.; Mülling, C. H. R.; Reese, S. Tegumento comum. In: König, H. E.; Liebich, H.-G. Anatomia dos animais domésticos: textos e atlas colorido. 1. ed. Porto Alegre: Artmed, 2004.

Brasil. Resolução Normativa CONCEA no 37, de 15 de janeiro de 2018. Available from: <https://www.mctic.gov.br/mctic/ opencms/institucional/concea/paginas/legis lacao.html>. Accessed on: Apr. 25, 2018.

Campelo, A. P. B. S.; Campelo, M. W. S.; Britto, G. A. C.; Ayala, A. P.; Guimarães, S. B.; Vasconcelos, P. R. L. An optimized animal model for partial and total skin thickness burns studies. Acta Cirurgica Brasileira, v. 26, Suppl. 1, p. 38-42, 2011. https://doi.org/10.1590/S0102-86502011 000700008 
Kim, J. Y.; Dunham, D. M.; Supp, D. M.; Sen, C. K.; Powell, H. M. Novel burn device for rapid, reproducible burn wound generation. Burns, v. 42 , p. 384-391, 2016. https://doi.org/ 10.1016/j.burns.2015.08.027

Medeiros, A.C.; Dantas-Filho, A. M. Cicatrização das feridas cirúrgicas. Journal of Surgical and Clinical Research, v. 7, p. 87102, 2016. https://doi.org/10.20398/ jscr.v7i2.11438

Rocha, C. L. J. V. Histofisiologia e classificação das queimaduras: consequências locais e sistêmicas das perdas teciduais em pacientes queimados. Interdisciplinary Journal of Experimental Studies, v.1, p. 140-147, 2009.

Santos, C. A.; Santos, A. A. Assistência de enfermagem no atendimento pré-hospitalar ao paciente queimado: uma revisão da literatura. Revista Brasileira de Queimaduras, v. 16, no. 1, p. 28-33, 2017.

Singer, A. J.; Hirth, D.; McClain, S. A.; Crawford, L.; Lin, F.; Clarck, R. A. F.; Validation of a vertical progression porcine burn model. Journal of Burn Care \& Research, v. 32 , p. 638-646, 2011.
https://doi.org/10.1097/BCR.0b013e31822 dc439

Tillmann, M. T.; Felix, S. R.; Mundstok, C. P.; Mucillo, G. B.; Fernandes, C. G.; Nobre, M. O. Tratamento e manejo de feridas cutâneas em cães e gatos (revisão de literatura). Nosso Clínico, n. 103, p. 2-19, 2015.

Vaughn, L.; Beckel, N. Severe burn injury, burn shock, and smoke inhalation injury in small animals. Part 1: Burn classification and pathophysiology. Journal of Veterinary Emergency and Critical Care, v. 22, p. 179186, 2012. https://doi.org/10.1111/j.14764431.2012.00727.x

Wohlsein, P.; Peters, M.; Schulze, C.; Baumgärtner, W. Thermal injuries in veterinary forensic pathology. Veterinary Pathology, v. 53, p. 1001-1017, 2016. https://doi.org/10.1177/030098581664336 8

License information: This is an open-access article distributed under the terms of the Creative Commons Attribution License, which permits unrestricted use, distribution, and reproduction in any medium, provided the original work is properly cited. 